\title{
PENGARUH KUALITAS INFORMASI DAN PEMENUHAN KEBUTUHAN INFORMASI PADA YOUTUBE CHANNEL "GADGETIN" TERHADAP KEPUTUSAN PEMBELIAN GADGET
}

\author{
Nurul Aini ${ }^{1 *}$, Sendi Eka Nanda ${ }^{2}$ \\ ${ }^{1,2}$ Fakultas Ilmu Komunikasi Gunadarma, Jl. Margonda Raya No. 100, Depok 16424, Jawa Barat, INDONESIA \\ Email: ${ }^{1}$ nurulaini.gunadarma@gmail.com; ${ }^{2}$ sendieka@ staff.gunadarma.ac.id \\ *Penulis korespondensi
}

\begin{abstract}
ABSTRAK
Penelitian ini bertujuan untuk mengetahui seberapa besar pengaruh kualitas informasi dan pemenuhan kebutuhan informasi pada Youtube channel GadgetIn terhadap keputusan pembelian gadget. Jenis penelitian menggunakan metode kuantitatif deskriptif. Teknik penarikan sampling menggunakan teknik Purposive Sampling. Teori uses and gratification digunakan sebagai landasan teoritis dalam penelitian ini. Metode pengumpulan data menggunakan kuesioner yang disebar pada 400 responden yang sesuai dengan kriteria peneliti yaitu subscribers Youtube channel GadgetIn yang berusia 20-25 tahun. Berdasarkan hasil penelitian kualitas informasi (X1) terhadap keputusan pembelian gadget (Y) memiliki pengaruh sebesar $18.1 \%$, hasil penelitian pada pemenuhan kebutuhan informasi pada Youtube channel GadgetIn (X2) terhadap keputusan pembelian gadget $(\mathrm{Y})$ memiliki pengaruh sebesar $26 \%$, secara simultan kualitas informasi dan pemenuhan kebutuhan informasi pada Youtube channel GadgetIn terhadap keputusan pembelian gadget memiliki pengaruh $28.5 \%$. Hasil koefisien determinasi sebesar $28.5 \%$ yang berarti pemenuhan kebutuhan informasi pada Youtube channel GadgetIn dipengaruhi kualitas informasi, sementara sisanya $71.5 \%$ dipengaruhi oleh faktor lain.
\end{abstract}

Kata kunci: Kualitas informasi; keputusan pembelian; pemenuhan kebutuhan informasi; teori uses and gratifiaction.

\begin{abstract}
This study aims to determine how much influence the quality of information and the fulfillment of information needs on Youtube channel gadget GadgetIn on purchasing decisions. This type of research uses descriptive quantitative method. Mechanical withdrawal sampling using purposive sampling technique. Uses and gratification theory is used as the theoretical foundation of this research. Methods of data collection using the questionnaire in the spread on 400 respondents who fit the criteria that researchers Youtube channel GadgetIn subscribers aged 20-25 years. Based on the research quality of information (X1) on purchasing decisions gadget (Y) has the effect of $18.1 \%$, the results of research on meeting the needs of information on Youtube channel GadgetIn (X2) on purchasing decisions gadget (Y) has the effect of 26\%, simultaneously the quality of information and the fulfillment of the Youtube channel GadgetIn information on purchasing decisions gadget has an influence $28.5 \%$. The result of determination coefficient of $28.5 \%$, which means fulfilment on Youtube channel information GadgetIn affected the quality of information, while the remaining $71.5 \%$ influenced by other factors.
\end{abstract}

Keywords: Decision to purchase; fulfillment of information needs; information quality; uses and gratification.

\section{PENDAHULUAN}

Di era teknologi sekarang ini, kemampuan internet dalam menjangkau khalayak ramai membuat internet banyak dilirik oleh berbagai kalangan khususnya media sosial. Teknologi dan perangkat media sudah memasuki beberapa aspek di dalam kehidupan. Adanya media sosial, masyarakat bisa menjangkau segala bentuk informasi dan hiburan dengan cepat dan mudah.

Perkembangan konvergensi media didukung oleh perkembangan teknologi komunikasi telah menghasilkan istilah baru yakni new media. New media atau media baru merupakan istilah yang digunakan untuk berbagai teknologi komunikasi yang berbagi ciri yang sama selain baru yang dimungkinkan dengan digitalisasi dan ketersediaanya yang luas untuk penggunaan pribadi sebagai alat komunikasi (McQuail, 2011).

Media sosial selain untuk menjalin atau mencari sebuah pertemanan, seiring dengan berjalannya waktu, media sosial berkembang menjadi tempat berbagi informasi dan hiburan.

Youtube adalah salah satu media sosial yaitu platform streaming video yang sangat populer saat ini setelah Instagram dan Twitter. Sejak kemunculannya pada tahun 2005, Youtube menjadi daya tarik sendiri bagi 
penggemarnya, banyak sekali orang yang ingin mengawali kariernya menjadi Youtuber yaitu sebutan sebagai pembuat konten di Youtube. pengakses Youtube pada tahun 2018 mencapai 1.8 milliar, dan pengguna Youtube di Indonesia menghabiskan waktu rata-rata 59 menit setiap harinya. Konten yang disajikan bermacam-macam seperti konten makanan, video blog ( $v \log )$, musik, horor, traveling, reviewer gadget.

Jumlah pengguna internet di Indonesia pada tahun 2019 menembus 175 juta atau sekitar 65,3\% dari total 268 juta penduduk Indonesia yang dilansir pada situs id.beritasatu.com yang diunggah pada tanggal 4 Januari 2019. Pada situs Mix.co.id yang diunggah pada 5 mei 2018, sekitar 92\% pertama kali mengakses Youtube untuk mencari konten video, sementara $91 \%$ menilai bahwa Youtube merupakan platform streaming video yang memiliki banyak konten kreatif, pada $87 \%$ mengakui bahwa video telah membantu pengguna untuk mencari konten video yang baru.

Pengguna gadget atau smartphone pada tahun 2019 meningkat signifikan dari tahun 2018, pada tahun 2018 pengguna smartphone mencapai 83,5 juta sedangkan pada tahun 2019 meningkat menjadi 92 juta, sekitar 8,5\% penduduk Indonesia menggunakan smartphone dan menjadi peringkat paling tinggi.

GadgetIn adalah salah satu channel Youtube yang membahas informasi mengenai gadget dan teknologi terbaru, bergabung pada tahun 2014. David Brendi adalah salah satu content creator yang membuat sebuah konten mengenai review gadget keluaran terbaru. GadgetIn berasal dari singkatan Gadget Indonesia yang mengawali debut pertamanya dengan video review handphone Xiaomi Mi 3. Saat ini GadgetIn sudah mempunyai 2 Juta subscriber dengan 562 video dalam 318,922,958 penayangan pertanggal 18 April 2019.

Di dalam era digital yang semakin hari semakin meningkat membuat tingkat konsumtif masyarakat terhadap internet sangat tinggi, dan setiap masyarakat mempunyai kebutuhan dan keinginan sesuai dengan harapannya untuk memperoleh keuntungan dari pencapaian tujuan yang sudah mereka tetapkan, maka dalam menghadapi tersebarnya informasi di berbagai media, masyarakat akan bertindak dan berlaku sama dalam rangka memenuhi kebutuhan informasi yang sudah di sajikan oleh media. Kualitas informasi pada suatu media menentukan bahwa informasi yang di sajikan oleh media sesuai dengan fakta atau tidak, semakin bagus tingkat kualitas informasi pada suatu media maka tingkat kepercayaan masyarakat untuk menerima informasi akan semakin tinggi, dan keputusan dalam membeli suatu gadget akan tinggi pula. Pada penelitian ini peneliti ingin mengetahui pengaruh kualitas informasi pada Youtube channel GadgetIn pada pemenuhan kebutuhan informasi masyarakat terhadap keputusan pembelian gadget. Oleh karena itu peneliti tertarik mengambil judul "Pengaruh Kualitas Informasi dan Pemenuhan Kebutuhan Informasi Pada Youtube Channel "GadgetIn" terhadap Keputusan Pembelian Gadget".

Berdasarkan penjelasan yang telah dikemukakan pada pendahuluan maka identifikasi masalah pada penelitian ini adalah "untuk mengetahui Pengaruh Kualitas Informasi dan Pemenuhan Kebutuhan Informasi Pada Youtube Channel "GadgetIn" terhadap Keputusan Pembelian Gadget".

\section{METODE PENELITIAN}

Pada penelitian ini, metode yang digunakan adalah dengan menggunakan kuantitatif deskriptif dimana data penelitian berupa angka-angka dan analisis yang menggunakan statistik (Sugiyono, 2010).

Data yang diperoleh didapatkan dari studi pustaka, studi lapangan, dan observasi. Studi pustaka didapatkan dari buku-buku, jurnal-jurnal, dan artikel-artikel yang berkaitan dengan dengan penelitian ini, studi lapangan dilakukan dengan menyebarkan kuesioner sesuai dengan judul penelitian, sedangkan observasi dilakukan dengan memahami fenomena yang ada untuk mendapatkan informasi yang dibutuhkan. Alat ukur yang digunakan menggunakan Skala Likert yang digunakan sebagai pengumpul data untuk mengukur sikap, pendapat dan persepsi seserang tentang suatu objek atau fenomena tertentu.

Sesuai dengan subjek penelitian yang sudah peneliti kemukakan, maka pelaksanaan penelitian ini tidak dibatasi pada satu wilayah saja, karena yang mensubscribe Youtube channel GadgetIn yang merupakan responden dari penelitian ini berada di wilayah yang berbeda-beda. Jadwal penelitian dilaksanakan dari bulan Mei hingga Juli 2019, proses tersebut sudah melingkupi pengambilan data responden melalui kuesioner, pengolahan data dan penyuntingan data.

Pada populasi yang akan diteliti adalah subscribers Youtube channel GadgetIn, berdasarkan peneliti temukan jumlah subscribers Youtube channel GadgetIn sebanyak 2.300 .000 pertanggal 18 Mei 2019. Dalam penelitian ini populasi akan diambil sesuai dengan kriteria dan karakteristik yang sudah peneliti tentukan yaitu berusia 20-25 tahun dan yang 
men-subscribe Youtube channel GadgetIn. Teknik sampling yang digunakan dalam penelitian ini adalah Non Probability Sampling dan metode penetapannya menggunakan Purposive Sampling untuk dijadikan sampel berdasarkan kriteria-kriteria tertentu (Siregar, 2013).

Sampel pada penelitian ini diambil dari populasi sebesar 2.300.000 dengan perhitungan rumus slovin dengan tingkat error 5\% dan di peroleh hasil sampel sebesar 400 responden.

\section{HASIL DAN PEMBAHASAN}

Dapat dilihat dari hasil pengumpulan data kuesioner yang disebar ke 400 responden yang memiliki kriteria sesuai dengan kriteria yang ditentukan oleh peneliti yaitu yang berusia 20-25 tahun dan telah mensubscribe Youtube channel GadgetIn, dapat diketahui bahwa jumlah responden yang lebih dominan berusia 21 tahun yang memiliki persentase $26 \%$. Hal ini menunjukan bahwa usia 21 tahun lebih aktif yang menggunakan gadget. Dari segi gender laki-laki lebih dominan dengan persentase 54\% menggunakan gadget dibandingkan wanita yang memiliki persentase $46 \%$, dan pendidikan terakhir responden $58 \%$ memilih SMA/SMK dengan status pekerjaan adalah pelajar yang memiliki persentase $62 \%$.

Penghasilan yang diperoleh responden kurang dari 1.000 .000 dengan persentase $52 \%$, kriteria di atas untuk mengetahui pengguna gadget aktif dan selain itu yang telah men-subscribe Youtube channel GadgetIn.

Tabel 1. Jenis Kelamin Responden

\begin{tabular}{cc}
\hline Jenis Kelamin & Hasil Persentase \\
\hline Laki-Laki & $54 \%$ \\
Perempuan & $46 \%$ \\
\hline
\end{tabular}

Tabel 2. Usia Responden

\begin{tabular}{cc}
\hline Usia Responden & Hasil Persentase \\
\hline 20 tahun & $23 \%$ \\
21 tahun & $26 \%$ \\
22 tahun & $22 \%$ \\
23 tahun & $15 \%$ \\
24 tahun & $8 \%$ \\
25 tahun & $6 \%$ \\
\hline
\end{tabular}

Tabel 3. Pendidikan Terakhir Responden

\begin{tabular}{cc}
\hline Pendidikan Terakhir & Hasil Persentase \\
\hline SMA/SMK & $58 \%$ \\
Diploma & $9 \%$ \\
Sarjana & $33 \%$ \\
\hline
\end{tabular}

Tabel 4. Pekerjaan Respoden

\begin{tabular}{cc}
\hline Pekerjaan Responden & Hasil Persentase \\
\hline Pelajar & $62 \%$ \\
Wiraswasta & $6 \%$ \\
Karyawan & $27 \%$ \\
Tidak Bekerja & $5 \%$ \\
\hline
\end{tabular}

\subsection{Uji Validitas}

Uji Validitas adalah untuk menunjukkan sejauh mana suatu alat ukur mampu mengukur apa yang ingin diukur dan fungsi dari uji validitas adalah untuk mengukur apakah pernyataan dari kuesioner tersebut sah atau tidak (Siregar, 2013). Nilai patokan $r$ hitung dari hasil uji validitas di atas adalah lebih besar 0.3610 , dengan tingkat signifikansi $5 \%$ yaitu 0.025 , maka dikatakan "valid".

Korelasi Pearson Product Moment untuk mencari arah dan kekuatan antar variabel bebas (X) dengan variabel terikat $(\mathrm{Y})$ dan data yang berbentuk rasio dan interval. Uji validitas pada penelitian ini dilakukan pada 30 responden yang men-subscribe Youtube channel GadgetIn. Hasil dari uji validitas dari masingmasing pernyataan lebih besar dari 0.3610 sehingga dapat memenuhi syarat validitas dan layak untuk dijadikan pernyataan dalam penelitian ini.

\subsection{Uji Reliabilitas}

Uji Realibilitas akan dilakukan dengan menggunakan teknik Alpha Cronbanch teknik ini bertujuan untuk melihat apakah suatu instrument reliable atau tidak, selain itu fungsi dari uji reliabilitas adalah untuk mengukur sejauh mana pengukuran dari suatu tes tetap konsisten meskipun telah dilakukan berulangulang. Kriteria suatu instrument akan dikatakan reliable dengan menggunakan teknik ini. Bila koefisien realibilitas (r11) $\geq 0.6$ maka dikatakan reliable (Siregar, 2013). Hasil uji reliabilitas dalam penelitian ini dikatakan reliable hasil alpha chronbach $0.932 \geq$ 0.6 .

\subsection{Uji Asumsi Klasik}

\subsubsection{Uji Normalitas}

Uji Normalitas adalah untuk melihat variabel $X$ dan variabel Y terdistribusi dengan normal atau tidak, jika data tersebut terdistribusi dengan normal maka dapat dilakukan uji hipotesis. Hasil dikatakan normal apabila nilai signifikansi lebih dari 0.05 maka data tersebut terdistribusi dengan normal, pada variabel kualitas informasi dan pemenuhan kebutuhan informasi pada Youtube channel GadgetIn dengan keputusan pembelian gadget terdistribusi dengan normal karena hasil dari uji kolmogrov-smirnov test menyatakan hasil yang diperoleh adalah sebesar $0.727>0.05$ 
sehingga ditarik kesimpulan bahwa data sampel diatas berdistribusi dengan normal, karena nilai Sig lebih besar dari 0.05 .

\subsubsection{Uji Multikolinearitas}

Uji multikolinearitas digunakan untuk mengetahui ada atau tidaknya korelasi antara variabel independent dalam model regresi. Model regresi yang baik adalah tidak mengandung multikolinearitas. Untuk mendeteksi multikolinearitas dapat melihat nilai tolerance dan varian inflation factor (VIF) menjadi tolak ukur (Ghozali, 2011). Untuk mengetahui ada atau tidaknya nilai korelasi antara variabel independent adalah jika nilai tolerance $\geq 0.10$ maka artinya tidak terjadi multikolinearitas dalam model regresi.

Penelitian yang baik adalah tidak terjadi multikolinieritas, dan hasil dari variabel independent yang sudah dihitung melalui SPSS 2.0 adalah nilai tolerance $0.664>10.00$ dan nilai VIF $1.505<10.00$ yang berarti tidak adanya tanda multikolinearitas dalam model regresi di data tersebut atau dengan istilah lain variabel independen memiliki model regresi yang baik.

\subsubsection{Uji Heterokedastisitas}

Uji Heteroskedastisitas digunakan untuk melihat apakah dalam uji regresi terjadi ketidaksamaan varian dari residual dari satu pengamatan ke pengamatan yang lainnya. Dalam model regresi yang baik tidak adanya gejela heteroskedastisitas yang terjadi, untuk penelitian digunakan uji glejser yaitu mengkorelasikan nilai absolut residual dengan masing-masing variabel. Hasil yang baik adalah jika nilai signifikansi (Sig.) $>0.05$ maka tidak terjadi gejala heteroskedastisitas dalam model regesi.

Pada penelitian ini hasil yang sudah dihitung melalui SPSS 2.0 adalah nilai signifikansi kualitas informasi 1.000 yang berarti $1.000>0.05$ dan nilai signifikansi kebutuhan informasi 1.000 yang berarti $1.000>0.05$. Dapat ditarik kesimpulan bahwa nilai signifikansi keduanya tidak terdapat gejala heterokedastisitas, maka data tersebut termasuk ke dalam model regresi yang baik.

\subsection{Analisis Regresi Berganda}

Regresi berganda yaitu alat yang dapat digunakan untuk memprediksi permintaan di masa yang akan dating berdasarkan data atau untuk mengetahui pengaruh satu atau lebih variabel independent (bebas) terhadap satu variabel dependent (terikat) (Siregar, 2013). Adapun dari rumus regresi berganda di atas dalam penelitian ini adalah sebagai berikut:

$$
\mathrm{Y}=\mathrm{a}+\mathrm{b} 1 \mathrm{X} 1+\mathrm{b} 2 \mathrm{X} 2+e
$$

Keterangan:

$$
\begin{array}{ll}
\mathrm{a} & =\text { Konstanta } \\
\mathrm{X} 1 & =\text { Kualitas Informasi } \\
\mathrm{X} 2 & =\text { Pemenuhan Kebutuhan Informasi } \\
\mathrm{Y} & =\text { Keputusan Pembelian } \\
\mathrm{b} 1, \mathrm{~b} 2 & =\text { Koefisien Regresi }
\end{array}
$$

$$
Y=14.196+0.146+0.465+e
$$

Nilai konstanta yaitu 14.196 memiliki nilai positif yang menunjukan bahwa variabel bebas (kualitas informasi dan pemenuhan kebutuhan informasi) berpengaruh pada variabel terikat (keputusan pembelian gadget), bila variabel bebas naik maka variabel terikat akan naik juga.

Pada kualitas informasi memiliki nilai 0.146 atau sekitar $14.6 \%$ menujukan bahwa variabel kualitas informasi berpengaruh positif pada variabel keputusan pembelian gadget, dan kebutuhan informasi memiliki nilai positif 0.465 atau sekitar $46.5 \%$ terhadap variabel keputusan pembelian gadget. Dapat disimpulkan bahwa semakin baik kualitas informasi dan pemenuhan kebutuhan informasi, maka akan naik pula keputusan pembelian gadget.

\subsection{Uji T (Secara Parsial)}

Uji T dilakukan untuk mengetahui seberapa pengaruhnya variabel bebas secara parsial terhadap variabel terikat, uji T dapat dilakukan dengan membandingkan $\mathrm{t}_{\text {hitung }}$ dengan $\mathrm{t}_{\text {tabel. }}$. Jika $\mathrm{t}_{\text {hitung }} \geq \mathrm{t}_{\text {tabel }}$ maka Ho diterima. Hasil dari uji t pada kualitas informasi (X1) terhadap keputusan pembelian gadget $(\mathrm{Y})$ mendapatkan hasil sebesar 3.756 yang berarti $3.756 \geq 1.966$. Dari hasil tersebut dapat di nyatakan bahwa kualitas informasi (X) mempunyai pengaruh yang positif terhadap keputusan pembelian gadget $(\mathrm{Y})$ yaitu Ho diterima dan Ha ditolak.

Hasil dari uji T pemenuhan kebutuhan informasi (X2) terhadap keputusan pembelian gadget $(\mathrm{Y})$ mendapatkan hasil sebesar 7.630 yang berarti yaitu $\mathrm{t}_{\text {hitung }} \geq \mathrm{t}$ tabel, $7.630 \geq 1.966$. Dapat ditarik kesimpulan dari penjelasan yang sudah di jabarkan adalah variabel bebas Pemenuhan Kebutuhan Informasi (X2) berpengaruh pada variabel terikat Keputusan Pembelian Gadget (Y) yaitu Ho diterima dan Ha ditolak. 


\subsection{Uji F (Secara Simultan)}

Uji F dilakukan untuk mengetahui seberapa berpengaruhnya variabel bebas terhadap variabel terikat secara bersama-sama, yaitu dapat dilakukan dengan membandingkan $f$ hitung $\geq f$ tabel maka Ho diterima. Hasil dari variabel X1, X2 terhadap Y yaitu kualitas informasi dan pemenuhan kebutuhan informasi Youtube channel GadgetIn terhadap keputusan pembelian gadget sebesar 79.294 yang berarti $\mathrm{f}$ hitung $\geq \mathrm{f}_{\text {tabel, }}, 79.294 \geq 3.86$. Dapat disimpulkan bahwa variabel Kualitas Informasi (X), Pemenuhan Kebutuhan Informasi (X2) secara bersama-sama berpengaruh terhadap variabel Keputusan Pembelian Gadget (Y) yaitu Ho akan diterima dan Ha ditolak.

\subsection{Koefisien Determinasi (Uji $\mathbf{R}^{2}$ )}

Uji $\mathrm{R}^{2}$ atau uji koefisien determinasi adalah angka yang menyatakan atau digunakan untuk mengetahui kontribusi atau sumbangan yang diberikan oleh sebuah variabel atau lebih variabel bebas (X) terhadap variabel terikat (Y) (Siregar, 2013). Pada nilai R square atau R2 yaitu koefisien determinasi terdapat pengaruh sebesar 0.285 , nilai tersebut menunjukan bahwa seluruh variabel bebas secara bersama-sama atau simultan mempengaruhi variabel terikat sebesar $28.5 \%$. Sisa dari hasil keseluruhan sebesar $71.5 \%$ karena beberapa faktor lain.

Tabel 5. Tabel Kategori $R^{2}$

\begin{tabular}{cc}
\hline Interval Koefisien & Tingkat Hubungan \\
\hline $0.00-0.199$ & Sangat Lemah \\
$0.20-0.399$ & Lemah \\
$0.40-0.599$ & Cukup Kuat \\
$0.60-0.799$ & Kuat \\
$0.80-1.000$ & Sangat Kuat \\
\hline
\end{tabular}

Sumber: Siregar, 2013

\subsection{Pembahasan}

Berdasarkan dari penjelasan di atas secara keseluruhan dapat di simpulkan bahwa, kualitas informasi di Youtube channel GadgetIn di kemas dengan baik dari segi tepat waktu, akurat dan relevan, sehingga subscribers lebih tertarik untuk mencari informasi lebih dan selalu menonton setiap videonya untuk mengikuti perkembangan gadget di Youtube channel GadgetIn. Pada pemenuhan kebutuhan informasi di Youtube channel GadgetIn masih dalam tingkat yang rendah, sehingga mempengaruhi keputusan pembelian gadget. Dari segi kualitas informasi yang di sajikan oleh Youtube channel GadgetIn sudah baik, namun itu belum cukup untuk memenuhi kebutuhan informasi bagi subscribers dari segi penyampaian informasi yang kurang spesifik dan sangat mempengaruhi keputusan dalam membeli gadget, karena subscribers butuh informasi yang lengkap dan jelas untuk memutuskan membeli gadget.

Teori uses and gratification menurut Blumer dan Katz bahwa tidak hanya satu jalan bagi khalayak untuk menggunakan media, sedangkan sebaliknya khalayak mempunyai banyak alasan untuk menggunakan media. Dari segi teori yang digunakan dalam penelitian ini adalah uses and gratification yang dimana dalam teori ini adalah pengguna aktif dalam menggunakan media serta penilaian terhadap isi media ditentukan oleh pengguna itu sendiri, disaat untuk mengonsumsi berbagai informasi dari media tertentu terdapat motif dari sisi pengguna tersebut. Inditifikasi masalah yang di ambil dari teori uses and gratification dalam penelitian ini adalah dari segi:

1. Jenis media

Jenis media yang diambil dalam penelitian ini adalah media sosial Youtube, dan objek yang di teliti Youtube channel GadgetIn yang memiliki 2 juta subscribers pertanggal 18 Mei 2019.

2. Isi media

Isi media dalam Youtube channel GadgetIn yaitu menyajikan informasi berbagai hal mengenai gadget secara aktual, menarik, dan lengkap.

3. Terpaan media

Terpaan media dibagi jadi beberapa indikator yaitu, frekuensi, durasi dan atensi. Pada penelitian ini subcribers dalam mengakses Youtube lebih dari 6 kali dalam seminggu dan memiliki persentase sebesar 64\%, sedangkan yang mengakses Youtube channel GadgetIn kurang dari 4 kali dalam seminggu dan memiliki persentase sebesar $61 \%$.

\section{Konteks sosial}

Konteks sosial dalam penelitian ini subscribers Youtube channel Gadget dalam segi gender lakilaki lebih dominan 54\% dibandingkan dengan perempuan sebesar $46 \%$ saja, dari segi usia 21 tahun memiliki persentase $26 \%$, dari segi pendidikan terakhir 58\% yang memilih SMA/SMK, dari segi pekerjaan $62 \%$ memilih pelajar, dan yang terakhir dari segi penghasilan 52\% memiliki penghasilan kurang dari 1.000.000.

Pada penelitian terdahulu yang peneliti gunakan sebagai landasan dalam penelitian ini membahas hal serupa yaitu kualitas informasi terhadap keputusan pembelian pembelian gadget. Penelitian yang berjudul "Pengaruh Kepercayaan dan Kualitas Informasi terhadap Keputusan Pembelian Secara Online Pada Situs www.traveloka.com" yang diteliti oleh Penia Anggraeni dan Putu Nia memiliki hasil yang signi- 
fikan pada kualitas informasi terhadap keputusan pembelian online yaitu sekitar $36.40 \%$. Hal ini memperkuat hasil dari penelitian mengenai kualitas informasi pada Youtube channel GadgetIn terhadap keputusan pembelian gadget yang mempengaruhi sekitar $42.5 \%$ dan hasil tersebut lebih tinggi dibandingkan dengan hasil pada penelitian terdahulu yang membahas hal yang serupa.

Pada penelitian terdahulu yang kedua membahas penelitian dari variabel pemenuhan kebutuhan informasi yang berjudul "Pengaruh Penggunaan Media Sosial Twitter Terhadap Pemenuhan Kebutuhan Informasi Tugas Akhir (Survei Terhadap Followers @TA_FEB" yang diteliti oleh Yoga Maulana Putra memiliki hasil yang signifikan pada penggunaan media sosial Twitter terhadap pemenuhan kebutuhan informasi sebesar $56.7 \%$ dan termasuk ke dalam kategori cukup kuat. Hal ini memperkuat hasil pada penelitian ini yang membahas pemenuhan kebutuhan informasi, meskipun dari segi variabel terikatnya berbeda dengan penelitian terdahulu, namun hasil dari pemenuhan kebutuhan informasi terhadap keputusan pembelian gadget memiliki nilai yang signifikan yaitu sebesar $51 \%$.

Pada penelitian terdahulu yang ketiga membahas mengenai "Pengaruh Terpaan Fitur Line Today Terhadap Pemenuhan Kebutuhan Informasi Mahasiswa Perguruan Tinggi Swasta di Kota Bandung" yang diteliti oleh Dior Triandra, Ayub Ilfandy Imran Ph.D memiliki hasil perhitungan terhadap pemenuhan kebutuhan informasi setelah mendapat terpaan informasi berada pada kateegori baik yaitu sebesar $72,9 \%$, artinya dapat diketahui terdapat pengaruh yang signifikan dari terpaan informasi ke pemenuhan kebutuhan informasi. Hal ini memperkuat hasil pada penelitian ini yang membahas pemenuhan kebutuhan informasi, meskipun dari segi variabel terikatnya berbeda dengan penelitian terdahulu, namun hasil dari pemenuhan kebutuhan informasi terhadap keputusan pembelian gadget memiliki nilai yang signifikan yaitu sebesar $51 \%$.

Dalam hal ini pengguna media berusaha mencari sumber informasi yang sesuai dengan kebutuhannya dan menilai kualitas informasi yang baik agar kebutuhannya dalam mencari informasi dapat terpenuhi dan ini sesuai dengan teori yang digunakan yaitu teori uses and gratification. Kesimpulan data dari 400 responden rata-rata subscribers Youtube channel GadgetIn adalah laki-laki dengan rata-rata usia 21 tahun, pendidikan terakhir adalah SMA/SMK, dan berpenghasilan rata-rata kurang dari 1.000 .000 pengguna aktif dalam menggunakan gadget dan yang men-subscribe Youtube channel GadgetIn.
Pengaruh kualitas informasi dan pemenuhan kebutuhan informasi pada Youtube channel "GadgetIn" terhadap keputusan pembelian gadget hanya mempengaruhi $28.5 \%$. sisa dari hasil keseluruhan sebesar $71.5 \%$ karena beberapa faktor lain tidak dimasukkan ke dalam penelitian ini.

Dapat disimpulkan bahwa Youtube channel GadgetIn dapat mempengaruhi subscribers setidaknya $53.4 \%$ untuk selalu mengakses Youtube channel GadgetIn dalam memenuhi kebutuhan informasi mengenai gadget. Sedangkan untuk subscribers itu sendiri mereka dapat memilah informasi yang sesuai dengan kebutuhannya dan menggunakan media mana yang ingin di akses untuk mencari kualitas informasi yang lebih baik selain di Youtube.

\section{KESIMPULAN DAN SARAN}

\subsection{Kesimpulan}

Berdasarkan hasil penelitian, maka peneliti membuat kesimpulan dalam penelitian ini, sebagai berikut:

1. Kualitas informasi (X1) secara parsial berpengaruh positif dan signifikan terhadap keputusan pembelian gadget sebesar 3.756 dan dapat disimpulkan bahwa kualitas informasi dapat mempengaruhi dalam keputusan pembelian gadget dengan memberikan informasi secara akurat, tepat waktu dan relevan. Hipotesis menunjukan H1 diterima dan Ho ditolak.

2. Pemenuhan kebutuhan informasi yang diperoleh melalui Youtube channel GadgetIn mempunyai pengaruh positif terhadap keputusan pembelian gadget sebesar 7.630 dan dapat disimpulkan bahwa pemenuhan kebutuhan informasi dapat mempengaruhi keputusan pembelian gadget karena Youtube channel GadgetIn mampu memenuhi kebutuhan subscribers dalam memberikan informasi mengenai gadget.

3. Hasil pengujian secara simultan menyatakan bahwa kualitas informasi dan pemenuhan kebutuhan informasi pada Youtube channel GadgetIn terhadap keputusan pembelian gadget hanya mempengaruhi $62.3 \%$ sisa hasil yang diolah yaitu $37.7 \%$ diluar dari faktor yang tidak dimasukan ke dalam penelitian.

\subsection{Saran}

Berdasarkan kesimpulan yang sudah dijabarkan di atas, peneliti memberikan beberapa saran sebagai berikut:

1. Bagi content creator GadgetIn diharapkan untuk meningkatkan kualitas informasi yang lebih baik lagi dalam menyajikan informasi kepada para penonton atau subscribers GadgetIn, sehingga para penonton dan para subscribers lebih terpe- 
nuhi kebutuhan informasi mengenai gadget dan tertarik untuk membeli gadget setelah menonton video di Youtube channel GadgetIn.

2. Bagi peneliti selanjutnya, penelitian ini diharapkan dapat menjadi referensi untuk penelitian selanjutnya, dan peneliti menganjurkan untuk menambahkan variabel selain pengaruh kualitas informasi (X1), pemenuhan kebutuhan informasi pada Youtube channel GadgetIn (X2) terhadap keputusan pembelian gadget (Y) agar lebih spesifik dan lebih melengkapi hal yang kurang dalam penelitian ini.

\section{DAFTAR PUSTAKA}

Abadi, R. (2014, Mei 2). Gadget Antara Kebutuhan dan Gaya Hidup. Dikutip dari 20 April 2019 dari Kreditgogo.com: https://kreditgogo.com/ artikel/Teknologi/Gadget-Antara-Kebutuhandan-Gaya-Hidup.html.

Adib, M. (2011). Filsafat Ilmu: Ontologi, Epistomologi, Aksiologi dan Logika Pengetahuan. Yogyakarta: Pustaka Belajar.

Alwisol. (2007). Psikologi Kepribadian. Malang: Universitas Muhammadiyah Malang.

Amstrong, P. K. (2012). Prinsip-prinsip Pemasaran. Jakarta: Erlangga.

Annisa, D. (2019). Pengaruh Kepercayaan, Kemudahan dan Kualitas Informasi Terhadap Keputusan Pembelian Online Melalui Aplikasi Shopee Studi Kasus Pada Mahasiswa Ilmu Komunikasi Universitas Mulawarman 2015-2017. eJournal Administrasi Bisnis, 2019, 7(1), 248261.

Annisa, D. (2019). Pengaruh Kepercayaan, Kemudahan dan Kualitas Informasi Terhadap Keputusan Pembelian Online Melalui Aplikasi Shopee Studi Kasus Pada Mahasiswa Ilmu Komunikasi Universitas Mulawarman 2015-2017. eJournal Administrasi Bisnis, 2019, 7(1), 248261.

Ardianto, E. (2007). Komunikasi Massa Suatu Pengantar. Bandung: Simbosa Rekatama Media.

Berger, C. R. (2015). Handbook Ilmu Komunikasi. Bandung: Nusa Media.

Burhanudin. (2015). Pengaruh Media Sosial Twitter @Lowekerpku Terhadap Pemenuhan Kebutuhan Informasi Lowongan Kerja Bagi Followers. Jom FISIP, Volume 2, No. 2.

Cangara, H. H. (2010). Pengantar Ilmu Komunikasi. Depok: PT. Raja Grafindo Persada.

Dior Trianda, A. I. (2017). Pengaruh Terpaan Fitur Line Today Terhadap Pemenuhan Kebutuhan Informasi Mahasiswa Perguruan Tinggi Swasta di Kota Bandung. e-Proceeding of Management, Vol.4, No.2, Page 1970.
Ellison, D. B. (2019, Juli 23). Social Network Sites: Definition, History, and Scholarship. Journal of Computer-Mediated Communication. Retrieved from jcmc.indiana.edu: http://jcmc.indiana.edu/ vol13/issue/boyd.ellison.html.

Fuady, H. K. (2018). Hubungan antara Tayangan Youtube "Female Daily Network" dengan Pemenuhan Kebutuhan Informasi Netizen. Volume 4, No. 2, Tahun 2018.

Ghozali, I. (2011). Aplikasi Analisis Multivariate dengan Program SPSS. Semarang: Badan Penerbit Universitas Diponegoro.

HS, L. (2009). Kamus Kepustakawanan Indonesia. Yogyakarta: Pustaka Book Publisher.

Indah, H. A. (2018). Pengaruh Inovasi Produk dan Harga Terhadap Keputusan Pembelian Sepeda Motor Yamaha di Kota Tangerang Selatan. Perspektif, Vol. XVI, No. 1.

Jogiyanto. (2009). Sistem Informasi Manajemen. Yogyakarta: Andi.

Katadata. (2015). Proyeksi Pengguna Smartphone di Asia Tenggara. Dikutip dari 31 Maret 2019 dari Katadata.co.id: https://databoks.katadata.co.id/ datapublish/2016/08/08/proyeksi-penggunasmartphone-di-asia-tenggara-2016-2019.

Katadata. (2019, Maret 6). Proyeksi Pengguna Smartphone di Asia Tenggara. Dikutip dari 10 April 2019 dari Katadata.co.id. Youtube Medsos No 1 di Indonesia. Dikutip Katadata.co.id: https://katadata.co.id/infografik/2019/03/06/Youtubemedsos-no-1-di-indonesia.

Keller, P. K. (2009). Manajemen Pemasaran Edisi Ketiga Belas. Jakarta: PT. Gelora Aksara Pratama.

Kotler, P. (2005). Manajemen Pemasaran. Jakarta: PT. Indeks Jakarta.

Kriyantono, R. (2006). Teknik Praktis Riset Komunikasi. Jakarta: PT. Kencana Perdana.

Madiawati, P. A. (2016). Pengaruh Kepercayaan dan Kualitas Informasi Terhadap Keputusan Pembelian Online Melalui Situs www.traveloka. com. e-Proceeding of Management, Vol.3, No.2, Page 1880.

McQuail, D. (2011). Teori Komunikasi Massa Edisi 6 Buku 1. Jakarta: Salemba Humanika.

Mulyanto. (2009). Sistem Informasi Konsep dan Aplikasi. Yogyakarta: Pustaka Belajar.

Muslim, A. (2019, Januari 4). Pengguna Internet Tembus 175 Juta. Dikutip 6 April 2019 dari id.beritasatu.com: https://id.beritasatu.com/ home/2019-pengguna-internet-tembus-175juta/184148.

Narimawati, U. (2008). Metodologi Penelitian Kualitatif dan Kuantitatif, Teori dan Aplikasi. Bandung: Agung Media.

Nasrullah, R. (2016). Media Sosial Perspektif Komunikasi, Budaya dan Sosioteknologi. Bandung: Simbiosa Rekatama Media. 
Nicholas, D. (2000). Assesing Information needs: tools, techniques and concepts for the internet age. London: Aslib, $2^{\text {nd }}$ ed.

Nurudin. (2015). Pengantar Komunikasi Massa. Jakarta: Rajawali Pers.

Putra, Y. M. (2015). Pengaruh Penggunaan Media Sosial Twitter Terhadap Pemenuhan Kebutuhan Informasi Tugas Akhir (Survei Terhadap Followers @TA_FEB).e-Proceeding of Management, Vol.2, Page 148.

Rakhmat, J. (2009). Psikologi Komunikasi. Bandung: PT. Remaja Rosdakarya.

Rijallahudin, R. D. (2016). Pengaruh Penggunaan Layanan Aplikasi Digital Google Play dalam Smartphone Terhadap Pemenuhan Kebutuhan Informasi Mahasiswa. Jurnal Komunikatio, Volume 2, Nomor 2, 135.

Shimp, T. (2003). Periklanan dan Promosi. Jakarta: Erlangga.

Siregar, S. (2013). Metode Kuantitatif dilengkapi dengan perbandingan perhitungan manual \& SPSS. Jakarta: Prenadamedia Group.

Sopiah, E. S. (2013). Perilaku Konsumen Pendekatan Praktis Disertasi Himpunan Jurnal Penelitian. Yogyakarta: C.V Andi Offset.

Studinews. (2017, November 2). Pengertian Informasi Menurut Para Ahli. Dikutip 28 April 2019 dari Studinews.com: https://www.studinews.co. id/2017/11/pengertian-informasi-menurut-paraahli.html.
Sugiyono. (2014). Metode Penelitian Kuantitatif, Kualitatif, dan Kombinasi (Mixed Methods). Bandung: Alfabeta.

Tjiptono, F. (2002). Strategi Pemasaran. Yogyakarta: Andi Yogyakarta.

Tri Harnoto, Y. B. (2018). Keputusan Pembelian Smartphone oleh Mahasiswa: Kelompok Acuan atau Gaya Hidup. MODUS, 30(2), pp. 181-197

Wati, Y. E. (2017). Pengaruh Terpaan Iklan Mie Sedap di Televisi Terhadap Keputusan Konsumen Membeli Produk Mie Sedap. Social Humanity:Jurnal Ilmu Sosial dan Humaniora, Volume 1, No. 1, pp. 24-31.

Wulandari, D. (2018, Agustus 3). Karakteristik Pengguna Youtube di Indonesia. Dikutip dari 31 Maret 2019 dari Mix.co.id: https://mix.co.id/ marcomm/news-trend/karakteristik-penggunaYoutube-di-indonesia

Yordan, J. (2018, Mei 5). Jumlah Pengguna Youtube Perbulan Capai 1.8 Milliar. Dikutip 31 Maret 2019 dari Kumparan.com: https://kumparan. com/@kumparantech/jumlah-penggunaYoutube-per-bulan-capai-1-8-milliar

Zebua, F. (2018, Maret 13). Smartphone Buying Decision Survey. Dikutip 31 Maret 2019 dari Dailysocial.id: https://dailysocial.id/report/post/ smartphone-buying-decision-survey-2018. 